\title{
The History of Korean Philosophy
}

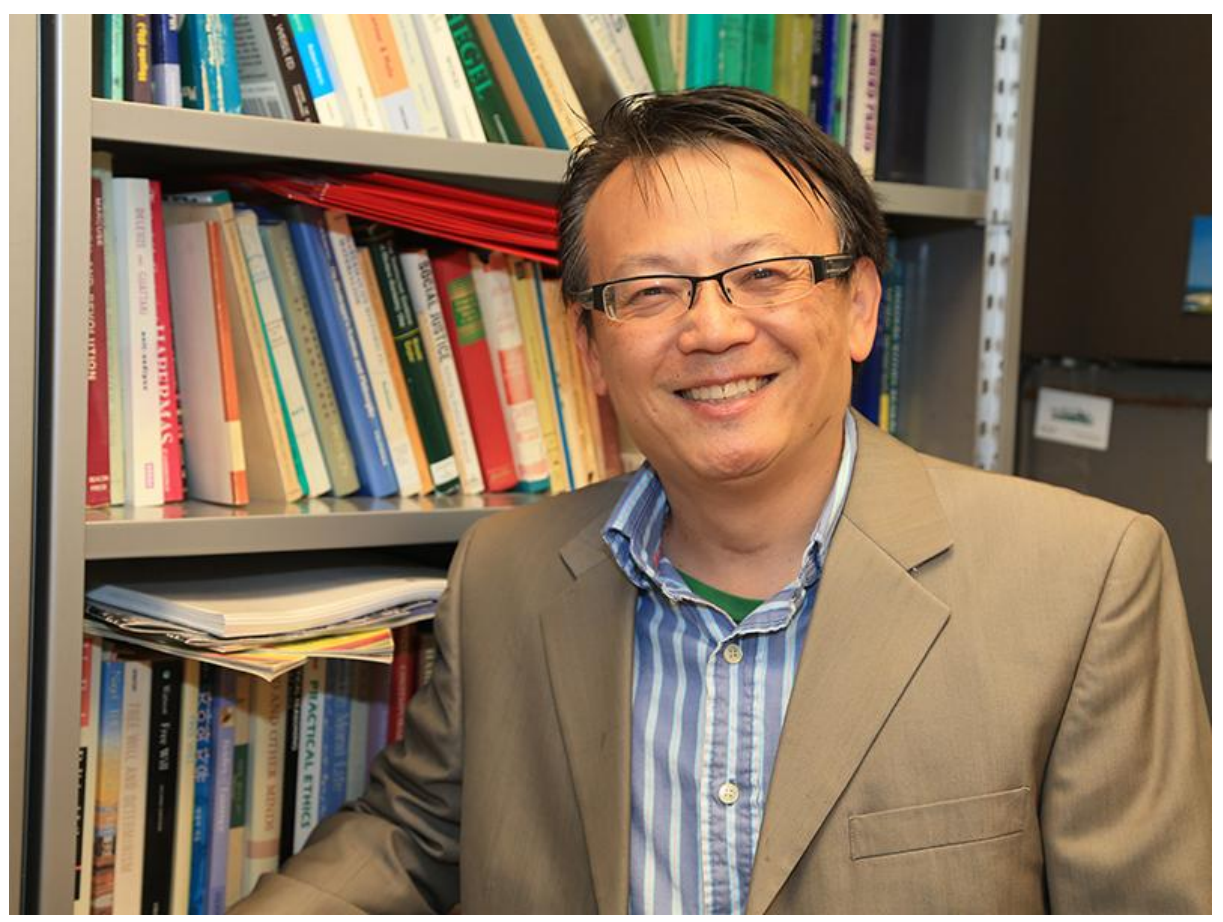

Halla Kim is professor of philosophy at Sogang University in Seoul, South Korea, and professor of philosophy and faculty member at the Schwalb Center for Israel and Jewish Studies at University of Nebraska at Omaha, USA. His recent publications include "Immanuel Kant" in Benjamin Crowe, ed., The Nineteenth Century Philosophy Reader (London: Routledge, 2015) and "Nothingness in Korean Buddhism: A Struggle against Nihilism" in JeeLoo Liu and Douglas Berger, eds., Nothingness in Asian Philosophy (London: Routledge, 2014). "Fichte on Fact/Act (Tathandlung)" and "Fichte's Philosophical Method" will appear shortly in M. Bykova, ed.The Bloomsbury Companion to Fichte. His articles also appeared in Locke Studies, Journal of Philosophical Research, and Recht und Frieden in der Philosophie Kants, among others. His own book Kant and the Foundations of Morality (Lanham, Maryland: Lexington Books, 2015) has just been published as well as his anthology (with S. Hoeltzel), Kant, Fichte and the Legacy of Transcendental Philosophy (Lanham, Maryland: Lexington Books, 2014). His latest anthologies include, Jewish Religious and Philosophical Ethics, together with C. Hutt and B. D. Lerner (Routledge, 2017) and Transcendental Inquiry: Its Origin, Method, and Critiques (with S. Hoeltzel) (Palgrave Macmillan, 2016). Currently he is writing an introductory book on the history of Korean philosophy (tentatively entitled "Korean Philosophy: A Historical Introduction") as well as preparing two anthologies, The Key Issues in Korean Philosophy (SUNY expected) and Beyond the Bounds of Sense: The Anniversary Issue of P.F Strawson's Bounds of Sense (Oxford: expected). He held visiting professorships at Osaka University (2017), University of Iowa Center for Asia and Pacific Studies (2001), Kyungpook National University, Korea (2011), University of San Francisco (2014), Katholike Universiteit Leuven, Belgium (2014), Shizuoka University, Japan (2015) and received grants from DAAD, Japan Foundation Center for Global Partnership, and the Academy of Korean Studies. Specializing in Kant/German Idealism, modern Jewish thoughts and Korean philosophy, he teaches a number of courses including history of modern philosophy, Kant, German Idealism as well as history of Korean philosophy 
and Asian philosophy. In 2013, he founded North American Korean Philosophical Association (NAKPA) as an affiliate group of the American Philosophical Association. He is also a frequent lecturer at the Global Day of Jewish Learning organized by the Jewish Federation of Omaha. Presently he is a member of American Philosophical Association, International Kant Society, Korean Kant Society, International Fichte Society, North American Kant Society, North American Fichte Society among others. He is also on the editorial board for Sogang Journal of Philosophy, Korean Journal of Philosophy, European Studies Journal, inter alia. He has served as referee for Journal of Korean Religions, Acta Koreana, Philosophy East and West, Journal of Chinese Philosophy, DAO: A Journal of Comparative Philosophy, Korean Studies, among others.

Tudor Petcu: At the beginning of our dialogue I wish to make reference to the meaning of Korean philosophy in the context of the universal philosophy. I mean I think it would be necessary to present in a relevant way the role that Korean philosophy has played in the evolution of the universal one, especially western philosophy. So, what could you say about this topic?

Halla Kim: The abstract thinking in Korea began with native religious thoughts (a version of shamanism) but it received a critical impetus from various thoughts originated from outside of Korea. Buddhism was originally conceived in India and greatly developed in China, but it was enthusiastically received and promoted during the Three Kingdoms Period (57 BCE - $668 \mathrm{CE}$ ) in Korea as well as Unified Silla (668 - 918) and Koryŏ dynasty (918 - 1392). Indeed, it played a critical and decisive role in the development of mature philosophical theorizing in Korea. Among many of its brilliant contributions, an attempt to achieve wisdom and perfection in an individual life and in a society under this light was an integral part of this tradition. Later in the 14th century, Buddhism gave hegemony to Neo-Confucianism which originally arose in Sung China. In particular, Chosŏn dynasty (1392 - 1910) in Korea turned out to be a fertile ground for its further development. For example, the idea of a morally superior person and a virtuous government of a community by such a figure, which culminated in the ideal of sage king, has occupied a central place in this effort.

Tudor Petcu: Which are the main philosophical approaches assumed over the years in the different academic milieus in Korea? Can we talk about a strong Korean phenomenology, or about any analytical Korean philosophy, or so? Every country where philosophy was assumed as a field of research has had a specific and general philosophical tradition, as for example England, very wellknown through its analytical philosophy, or Germany through its idealism or phenomenology expressed by Edmund Husserl or Martin Heidegger. In this case, what about the philosophical tradition in Korea?

Halla Kim: Since the turn of the twentieth century, Korean philosophers have been paying close attention to Western philosophical traditions, first to continental philosophy such as German Idealism, Marxism, phenomenology and existentialism. More recently, they began showing keen interest in analytic philosophy. However, hardly any one of them took root in Korea and developed a distinctively Korean (i.e., original) form of thought as a school. However, the situation is different with more traditional philosophy, such as Buddhism, and especially Confucianism. There is no question the Korea Confucianism originated from China but since the fifteenth century Koreans began producing highly distinctive and sophisticated form of Neo-Confucianism. This domesticated from of Confucianism has 
something to do with the issues those philosophers were concerned with, especially the issues in moral psychology and sage learning. Koreans generally subscribed to the Mencian idea of moral foundations in human nature (in particular the idea of Four Sprouts, i.e., sympathy, shame, deference and right/wrong) and also the metaphysical ramification and development of the idea in Neo-Confucianism of the Song dynasty in China. However, the Koreans were very sensitive about human vulnerability to moral evil in the path of self-cultivation, and subjected the emotional aspects of the vulnerability and its resolution to sharpest analyses and far-reaching insights. For example, the Neo-Confucian philosopher T'oegye (1502 - 1571) argued that this frailty in human psychology must be properly dealt with by a recourse to a metaphysically loaded conception of normativity in what he calls the "rational principle ("li")'. As opposed to that, his younger contemporary Yulgok (1536 - 1584) suggested that the embodied force of psycho-physical nature ("ki") played a more active role in overcoming our frailty. This famous debate over the origin of Four Spouts and Seven Emotions (such as joy, sorrow, desire, etc.) later spilled over to another debate ("Horak debate") where Han Wŏnjin (1681 - 1751) and Yi Kan (1677 - 1727) had a lengthy discussion over whether there is any difference between human nature and sub-human nature, and also over what, and how much, shelter human nature can provide from evil in the context of moral community. In the eighteenth century, a group of practically oriented philosophers led by Tasan $(1762$ - 1836) rejected the metaphysically oriented framework such debates presupposed and supplied instead highly naturalistic principles of cosmology and sage learning, sometimes even borrowing from the Jesuit writings to create a theistic Confucianism. Toward the end of the nineteenth century amidst the onset of the foreign/Western influences, Ch'oe Che-u (1824-1864) invented the first indigenous form of philosophy/religion called "Tonghak (Eastern Learning)" with an emphasis on the internalized conception of heaven in humans. Then in the early to mi-twentieth century, a highly self-conscious group of Korean Christians developed a distinctive form of indigenized philosophical theology by identifying God with nothingness, thus effecting a synthesis of Western theology with East Asian traditions. Ryu Young-Mo (1890 - 1981), Kim Kyŏsin (1901 - 1945) and Ham Sŏkhŏn (1901 - 1989) are among those who developed this syncretism.

Tudor Petcu: Western philosophy has always accorded a huge attention to the relation between philosophy and religion although it is difficult to find too many common denominators, first of all because of their comprehensive logics. Of course, from this point of view there would be a lot to say, especially if we should take into account the modal logics as a way to explain the Reality in comparison with religion, mostly based on a mystical worldview which has its own logics. But we shouldn't forget about the different Christian efforts in the Middle Age to create a liaison, a strong connection between philosophy and religion, as Saint Anselm or Thomas Aquinas did. Anyway, what can you say about the way the relation between philosophy and religion was defined in Korea and who were the main Korean philosophers focused on the analyses of this topic?

Halla Kim: Philosophy and religion go hand in hand in the traditional Korean Philosophy.In his "Eleven Theses on Feuerbach," Karl Marx claims that "the philosophers have only interpreted the world, in various ways. The point, however, is to change it," thus incisively criticizing the abstract, isolated way that philosophy in the West had been practiced, in separation from the true reality of the world. According to Marx's conception, philosophy is to be fundamentally practical beyond 'theories,' both simple and complex (from the Greek verb, "theorein"). Marx's criticism, however, would be completely pointless if directed against the Korean Neo-Confucianism/Buddhism. For the latter has always been preoccupied with a concrete praxis in the daily context. Neo-Confucianism and Buddhism is, by its very nature, fundamentally practical, regardless of any shortcomings it is occasionally perceived to have. 
In the familiar division of philosophy influenced by Western approaches, we commonly conceive it as being composed of three parts: metaphysics, ethics and epistemology. For Korean philosophy, this would be completely inadequate. For it miserably fails to capture the most essential part of it; the art of self-cultivation (or as we can put it, "a way of life and thought") is the most important part of philosophy proper. Just like metaphysics, epistemology, and ethics, the art of self-cultivation (which I propose to call "Eu-praxia") surely has theoretical components but the most essential component of it is its practical part. One who studies it must not only understand it or theoretically know about it but also must internalize it and actively practice it in his or her concrete relation with others. This is why it is different from theoretical disciplines (including the typically theoretical 'philosophical ethics' as it is widely taught in academia). You don't have to be ethical to teach philosophical ethics but you cannot teach/transmit Eu-praxia without exemplifying it yourself. There should be a unity of thought and action in the art. The Neo-Confucian/Buddhist reflection can be on things in the world but it must be directed toward oneself, thus "self-reflection."

Tudor Petcu: Would it be correct to say that Buddhism as worldview represents one of the most important foundations of Korean philosophy?

Halla Kim: As Charles Muller suggests, Korean Buddhism is distinctive within the broader field of East Asian Buddhism for the pronounced degree of its syncretic discourse. Korean Buddhist monks throughout history have demonstrated a marked tendency in their essays and commentaries to focus on the solution of disagreements between various sects within Buddhism, or on conflicts between Buddhism and other religions. While a strong ecumenical tendency is noticeable in the writings of dozens of Korean monks, among the most prominent in regard to their exposition of syncretic philosophy are Wŏnhyo (元曉 617 - 686), Pojo Chinul (普照知訥 1158 - 1210) and Hamhŏ Kihwa (涵虚已和 $1376-1433$ ).

The main operative conceptual framework within which these scholar-monks achieved their syncretic vision is derived from the metaphysics connected with the Hwaŏm (華嚴 Ch. Hua-yen) school, as well as the soteriological discourse of the closely related Awakening of Faith (大乘起信論) tradition, both of which have dual roots in Indian Buddhist and native East Asian philosophy. Among all the earliest forms of Buddhism, the most outstanding is the synoptic philosophy of Wonhyo. According to him, the most fundamental Buddhist doctrines are to be understood from the logic of interfusion which enables him to embrace and harmonize different strands of Buddhism without forsaking the substance of them. His view then culminates in the metaphysics of One Mind with its soteriological implications. Then the holism of Üisang (625 - 702) and his Hwaŏm Buddhism is discussed with an account of his Ocean Seal Chart (華嚴一乘法界道) followed by a brief discussion of Pure Land Buddhism and Consciousness-Only School in unified Silla dynasty. No discussion of Korean Buddhism is complete without Chinul, the founder of Sŏn (c. Chan, j. Zen) Buddhism in Korea. Chinul's Sŏn philosophy with a focus on the notion of "True Mind" is developed in the scheme of Sudden Enlightenment to our true nature under the guise of emptiness followed by a Gradual Cultivation. This gave rise to the age-long controversy over Tonjŏm debate, i.e., Sudden Enlightenment vs. Gradual Development in Korea. Indeed, defying Chinul, T'aego Pou (1301 - 1382), towards the end of Koryŏ, the final "national master," emphasized Buddhism as a quintessentially practical discipline where both awakening and cultivation are fully realized in one fell swoop. This effort of Chinul and T'aego Pou were later continued by Chosŏn Buddhist monks, especially, Kihwa and Sŏsan (1520 - 1601). In addition, the well-known Neo-Confucian attack on Buddhism, in particular, the attack on the quintessential Buddhist concept of emptiness around the time of the foundation of Chosorn 
dynasty, is in this respect unfounded, for Buddhism simply does not entail nihilism conceived as expressing a fatalistic stance about the forces of nature (including human nature) with a strong implication for inaction and despair.

Tudor Petcu: We shouldn't forget to highlight the contemporary philosophical theories in Korea, because in our days it's very hard to find a philosophical task given the technological revolution and the development of pragmatism. I am saying that because the general question that is addressed even in the British and American schools of philosophy is the following one: what role can philosophy play in our days, in a society where science is evolving on and on? But in spite of this fact and according to the question I have mentioned above, there are numerous contemporary philosophical views related especially to politics, science and economics. So, which are the most important contemporary Korean philosophical theories and approaches?

Halla Kim: I hope to promote the value and significance of Korean philosophy in the very context of the age of globalization without forsaking our deep-rooted tradition in Buddhism, Neo-Confucianism and Tonghak (Eastern Learning) among others. This is why the topic of Korean philosophy as such and its modernity is important. Our vision is that there is something very valuable in the traditional Korean thought but this merit cannot be fully appreciated until we consider it in light of the achievement and dynamics of western philosophy. Therein lies the importance of East-West comparative philosophy, in particular, East-West comparative ethics. The latter is all the more important because Koreans traditionally prided themselves on epitomizing the value of morality "in the East." The issues in traditional moral theories can best be elucidated and illuminated by the recent development and achievement in moral and cognitive psychology (e.g., the moral modularity hypothesis). Finally, we plan to approach and analyze many of the major issues in traditional Korean philosophy in the context of this comparative scheme and provide new answers to those old questions. For example, we strongly hope to come up with a contemporary understanding of the essential notion of li and ki as well as the causal concepts such as "produce" (pal), "ride" (sŭng), "begets" (saeng). Thus, we can see that all these topics, i.e., philosophy and modernity, East and West comparative philosophy, some major issues in the history of Korean philosophy, Korean Neo-Confucianism and its moral psychology as well as the EastWest comparative moral philosophy, are all closely intertwined in the context of the comparative approaches to the problems in Korean philosophy against the most recent development in Western philosophy.

Korean philosophy today is in its unique, particularized situation in the Korean peninsula and it can be best illuminated when we historically revisit the socio-political-economic-intellectual development up to now since 1945. Korea was freed from the Japanese colonial rule $(1910-1945)$ as soon as WW II ended. At that time, there were fierce ideological disputes between socialists and liberalists. Since then until now, North Korea has followed Marx-Leninism and Juche (self-reliance) Ideology of its communist founder Kim Il-sŏng, while South Korea has discussed various theories of philosophy under liberalism. Thus, the South Korean philosophy in the 1950s and 60s leaned toward German Idealism and Existentialism. This inclination was natural for the South Korean philosophers who experienced Japan's colonialism and the Korean War $(1950$ - 1953). The South Koreans had to gather powers in order not to lose the sovereignty of nation and recover the loss of human dignity from the war. At that time, the leading ideology was one-nation-ism (一民主義) that we are one ethnic race speaking one language. Such a strong nationalism in South Korea led to staunch anti-communism. This anti-communism was combined with the nation theory of Fichte and Hegel. The combination of nationalism and anti-communism remained unchanged until the pro-democratic resistance movement in June of 1987 occurred. In this situation, even liberalism was regarded as an impure thought. Korean 
traditional thoughts were deemed valuable only to the degree to which it supported nationalism. Therefore, South Koreans could not enjoy the freedom of thoughts much like North Koreas. However, the philosophers in South Korea made incessant efforts to achieve democratization. They actively discussed the social critical theory of Frankfurt Schools in the 1970s, Marx-Leninism and North Korean Juche-Ideology in the 1980s, and neo-rationalism, post-Marxism, and post-structuralism in the 1990s. Finally, the issue of environmental value and welfarism came to the fore in the 2000's. They made continual efforts for the purpose of democratization as well. Of course, these efforts were chiefly made rather outside the academic circle rather than in it. The philosophers in academia concentrated on German Idealism, Existentialism, Phenomenology, English and American Analytical Philosophy, East Asian Philosophy, and Korean traditional philosophy. Although there were conflicts between the philosophical activities within academia and those outside of it, various schools of philosophy emerged in South Korea in contrast to North Korea. South Korean philosophers have discussed philosophy in various ways in order to solve the conflicts between Korean traditional philosophy and the trendy Western philosophy, and then they tried to recover the identity of Korean philosophy which they lost during the 36 years of Japan's colonial rules. They have also discussed the true modernization of their community. Furthermore, they have discussed how to unify South and North Korea. True, it must be acknowledged that there were conflicts between the traditional Korean philosophy and the Western philosophy in the process. But we hope to elevate and develop this into productive communication between the two. This is the area in which East and West comparative framework can be considered and employed most fruitfully.

The traditional Korean philosophy is also relevant to the issues of ecological value as well as communal value. Korean philosophers have been doing their best to make contributions to the issue of environmental values in their research agenda (e.g., post-modern variations with a touch of Daoism). The communal value is addressed, too, as can be seen in the traditional Confucian communitarianism. The Korean society has now reached a critical juncture where its tradition has come into conflict with modernity and postmodernity. Its modernization was achieved not by the revolution from below but by the order imposed from above. In a word, the Korean society was modernized in the pre-modern way. Strictly speaking, the Korean society was not modernized until the pro-democratic resistance movement in June of 1987 took place. However, on the one hand, strong collectivism still exists in the Korean society, and, on the other hand, strong egocentrism thrives. Furthermore, Koreans achieved a certain measure of success of modernization at the price of environmental disasters such as the pollution of the air as well as the rivers among others. New philosophical ideasare being sought to shed lights on how to solve these problems as Koreans are now faced with the task of harmonizing the Confucian communitarianism of their traditional society with the modern libertarianism of the Western society. Some of them say that we have to recreate the Western modernity on the basis of our tradition, and some of them say that we have to keep alive our tradition on the basis of the Western modernity. Others say that we have to follow either post-modernity respecting difference among one another from the viewpoint of Post-structuralism, or the 'autonomous movement' from the point of the SpinozaMarxism. Now, some South Korean philosophers accept the theory of J. Habermas and J. Rawls, but others are sympathetic to the theory of A. MacIntyre, M. Sandel, and C. Taylor in order to synthesize the new tradition and modernity after 1987. Of course, there is also an attempt to solve the problem of modernization from the standpoint of Post-Marxism and Spinoza-Marxism, especially G. Deleuze, and A. Negri. In addition, many South Korean philosophers are seriously discussing this issue in regard to our Confucianism, too. The philosophers inclined toward communitarianism contend that Koreans should not accept the liberalism of the West. They say that the liberalism is not suitable for Koreans because our way of life is essentially based on Confucianism. According to their view, South Korean society is now more individualistic than any other society, and so they must develop the Confucian 
communitarianism in order to solve this problem. From this angle, they must also recreate the Confucian value in the economic sphere as well as in the political sphere for the purpose of realizing the truly East Asian value. (updated May 1, 2018) 